\title{
Perception of trainers and students on the measures to be taken to solve the addiction of young people to social networks
}

\author{
Rubicelia Valencia-Ortiz \\ rubivalencia@gmail.com \\ MacMillan Education México / UPV/EHU, Mexico \\ Julio Cabero-Almenara \\ cabero@us.es \\ University of Seville, Spain \\ Urtza Garay Ruiz \\ urtza.garay@ehu.eus \\ University of the Basque Country (UPV/EHU), Spain
}

\begin{abstract}
Addictions to online social networks is a problem facing technological societies, and those most affected by this phenomenon are young people and teenagers. Among its effects are the decrease in academic performance and the increase in violent behavior. Given these facts, governments around the world are adopting mechanisms for their prevention. The presents work describes the results of research focused on investigating the proposals that would be adopted by the members of the educational community to carry out preventive actions against the addiction and abuse of online social networks. The methodological design has been based on the intensive use of the Nominal Groups technique developed by Delbecq and Andrew in 1971 and which facilitates reaching consensus in a structured group process. The results show the high degree of coincidence among the participant stands out, which validates the usefulness of the measures, and that the addiction to social networks perceives it as a direct consequence of the addition to mobile phones and the Internet. Therefore, it seems necessary that prevention plans should have a generalized perspective that encompasses all three technologies.
\end{abstract}

\section{Keywords}

Social networks; Internet; addition; education 


\section{One problem in the technological society: Addiction to online social network- ing}

Addiction to social media is becoming a problem in technological society, even abroad US. Missouri's senator is promoting an initiative "Social Media Addiction Reduction Technology Act, (https://bit.ly/307YiNt) to stop the mechanisms some technology firms use to make users spend so much time stuck to their tech devices. This is an answer to the consequences of the troublesome situations that are occurring nowadays.

A tv network in Spain has recently launched the campaign "Levanta tu cabeza" (Rise your head) (https://bit.ly/3dEZenr) to create practices of conscious usage in technologies and thus to achieve changes in habits and behaviors toward this technologies.

There is also "Proyecto Hombre" (project Man) (http://proyectohombre.es/) that is an institution dedicated to treat addiction problems. It started to treat drug addictions and alcoholism but nowadays it has included behavioral treatment (chats and mobile addictions)

Data from different researches (Bruno, Scimeca, Cava, Pandolfo, Zoccali y Muscatel, 2014; Meena, Navpreet, Kavnet, Navreet, Parminder y Parwinder, 2015; Ganesh, Pragyakumari, Ramsudarsan, Rajkumar, Shyam y Balaji, 2017) point a major usage of social media among youngsters and teenagers to communicate with each other. Tejada, Castaño and Romero established (2019):

\footnotetext{
"Youngsters who use social networking to define their individual characteristics and determine their thoughts, validate this usage as they are accepted by others who feel they represented or reflect an identity likeness. If they also receive social support from those who they connect with then emotional bonds are developed. However, this interaction itself represents a risk of its own, because it depends on the people they are in touch with and how this interaction is done." (Tejada, Castaño y Romero, 2019: 124).
}

In parallel to this rise, there are investigations that indicate the different pernicious effects of this abuse for several aspects and variables: Sleeping problems (Cañón and others, 2016; Xanidis y Brignell, 2018; Gordo, García, De Rivera and Díaz-Catalán, 2018), low scholar achievements, high scholar failures (Kim, Kim, Park, Kim y Choi, 2017; Malo, Martín and Viñas, 2018; Lacka et al., 2021), social isolation (Yu, Wu, and Pesigan, 2016), cognitive flexibility dificulties (Dong, Lin, Zhou \& Lu, 2014), problems to make decision (D'Hondt, Billieux \& Maurage, 2015), a rise in the anxiety level (Wegmann, Stodt \& Brand, 2015), omission of certain actvities (Chóliz \& Marco, 2012), violent conducts such as bullying and cyberbullying (Martín, Pazos, Montilla and Romero, 2016; Martínez-Ferrer and Moreno, 2017), low mood (Gómez, 2014), low selfsteem (Lee and Cheung, 2014) or conflcts to get concentate (Rücker, Akre, Berchtold \& Suris, 2015).

These troblesome situations have led to different authors to propose various analysis scales in order to diagnose the addiction (Basteiro, et al., 2013; Escurra \& Salas, 2014; Tutgun-Ünal \& Deniz, 2015; Orosz, Tóth-Király \& Bőthe, 2016; Banyai, et al., 2017; Simó, Martínez, Ballester \& Domínguez, 2017; Ávila, Pardo and Muñoz, 2018; Liu \& Mba, 2018; Sigerson \& Cheng, 2018; Valencia and Castaño, 2019; Salcines-Talledo, González-Fernández \& Briones, 2020)

Nevertheless, there are so few proposals presented to treat this situation in educative institutions, and because of this perspective, we insert the present work, in search of actions derived from the people that are directly involved in youngster's education. 


\section{The investigation}

\section{a. Targets of the investigation}

The investigation is part of a much wider one which has as general objective: to know the level of addiction that students in Highschool grade have to Online Social Networks (OSN). The present research pretends to: explore through members of the educative community, students, teachers, counselors, and parents, to get formative proposals that can be adopted in order to prevent OSN addiction and abuse by youngsters and teenagers.

\section{b. The sample}

Partcipants who applied the Nominal group(NG) technique came from Colegio de Bachilleres in Mexico; a Mexican institution (https://www.gob.mx/bachilleres) that offers labor skills formation for high school students, so they would be prepared, wether they continue their studies at a University or not, to work professionally. The students and teachers had participated in an experimental stage of the investigation by fulfilling an adaptation of the "social media addiction Scale-Student Form" from Sahin (2018). To build it there were some conditions defined as follows:

- At least 4 work teams, each with 10 people

- Different elements from the educative community shall conform the groups: 2 students, 2 teachers from different subjects, counselors, fathers and mothers.

- The participants should come from two different campus of the Institution: 1 from El Rosario in Azcapotzalco, located in Mexico City, and 5 from Satelite, located in the State of Mexico.

- A specific area and time must be established to have a worktime session with each group, at least during 90 minutes each.

Students' age was between 16 and 18 years old, including 12 women and 8 men. The group with teachers, parents and counselors were between 28 and 69 years old. There were 10 women and 10 men from different departments in school. 14 from teaching positions, 5 counselors and 1 from the administrative area.

\section{c. Collecting data technique: Nominal groups}

We applied Nominal Group technique (Nominal Group Technique") developed by Delbecq and Andrew (1971) because this creative technique eases the brainstorming and the analysis of the problems. It is hopefully the suitable way to reach a fast consensus in different aspects: problems, circumstances, solving problems and the viability of projects. Olaz (2012) said that "it is born to improve the teamwork development and operative actions such as the productivity demanded to the groups". (Olaz, 2012, 143).

On the other hand, Manera, Hanson, Gutman and Tong (2018) draw the attention to the fact that "it is a process of structured group that it is used to achieve consensus in the members. The process involves that the participants are able to identify and give ideas about a topic or a question that the facilitator presents. Then the participants discuss and prioritize the ideas individually". (Gutman and Tong, 2018: 2) According to some authors, this technique is a high structured tool that combines characteristics of an individual questionnaire and focal groups as well (Vander, 2015).

The advantages indicated for NG's are diverse: It is easy to organize and you can obtain classified information; you can easily have the participation of all the members of the group; the influence of the researcher is limited as the influence he or she could have in the dynamic of the group. You can use it in different moments of the study, maybe in the exploratory stage or during the generation of a hypothesis or to evaluate the most meaningful conclusions. It minimizes the competitiveness 
between members of the group, and they are concerned if some are not participating. And costbenefit standard: There's no need to transcript or analyzing (Mogollón y Vázquez, 2008; VargaAtkins, 2011; Vander, 2015; Manera, Hanson, Gutman and Tong, 2018).

When we detect its limitants, there could be a rush in the final decision and if they had more time to analyze or to discuss the information, the results could be different. High creativity students can feel inhibited by the process structure. The costs of the realization might be high if the people must commute, or maybe the time to develop the experience (Harvey y Holmes, 2012; Lennon, Glasper y Carpenter, 2012; Peña, Estrada, Debbie, Taylor. y Burton, 2012).

There are offered diverse recommendations to achieve an effective application, such as the size of the groups, preferably 10 members (Lennon, Glasper y Carpenter, 2012; Olaz, 2012; Peña, Estrada, Debbie Taylor and Burton, 2012); the skills of the researcher-leader of the NG, he/she must be capable of creating a nice environment and managing the speaking and non verbal language, so the communication and participation of the members are guaranteed; the questions must be clear and understandable for the participants, and time should not be more than 150 minutes.

There are some stages to get it started, and according to different authors (Varga-Atkins, 2011; Olaz, 2012; McMillan, Kelly, Sav, Kendall \& King, 2014; Humphrey-Murtoa, Varpio, Gonsalves \& Wood, 2017; Hugé y Mukherjee, 2018), are a)introduction of the objective for the session and the rules to function; b) Individual brainstorming to solve the raised problem; c) to share the ideas or proposals in the group d) discussion, review and analysis of the group ideas and to perform a final list of proposals e) vote and classify the answers f) closure and acknowledgment $g$ ) data analysis.

It is finally specified that applying this instrument is reaching different fields: medicine (Rice and others), Criminology (Vander, 2015), ecology (Hugé and Muckherjee, 2018), the organization of institutions like hospitals (Peña, Estrada, Debbie Taylor and Burton, 2012) and education (Rodríguez-Gallego, 2014).

\section{d. Results}

The phases after the instrument was implemented were previously named: introduction and framing, the generation of ideas (fig.1). The registration of ideas and proposals is shared. (fig 1.) The discussion, review and analysis of the ideas inside the group. (fig. 3), voting and classifying the answers (fig. 4), closure and acknowledgment.

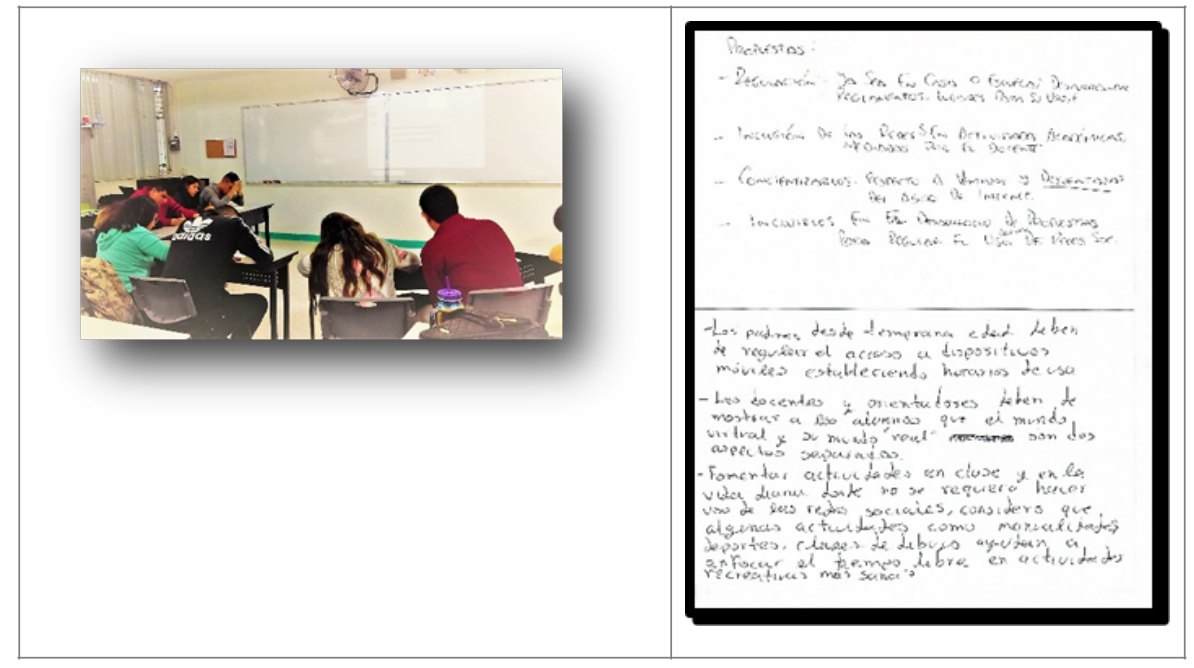

Figure 1. Making ideas / Source: own elaboration 


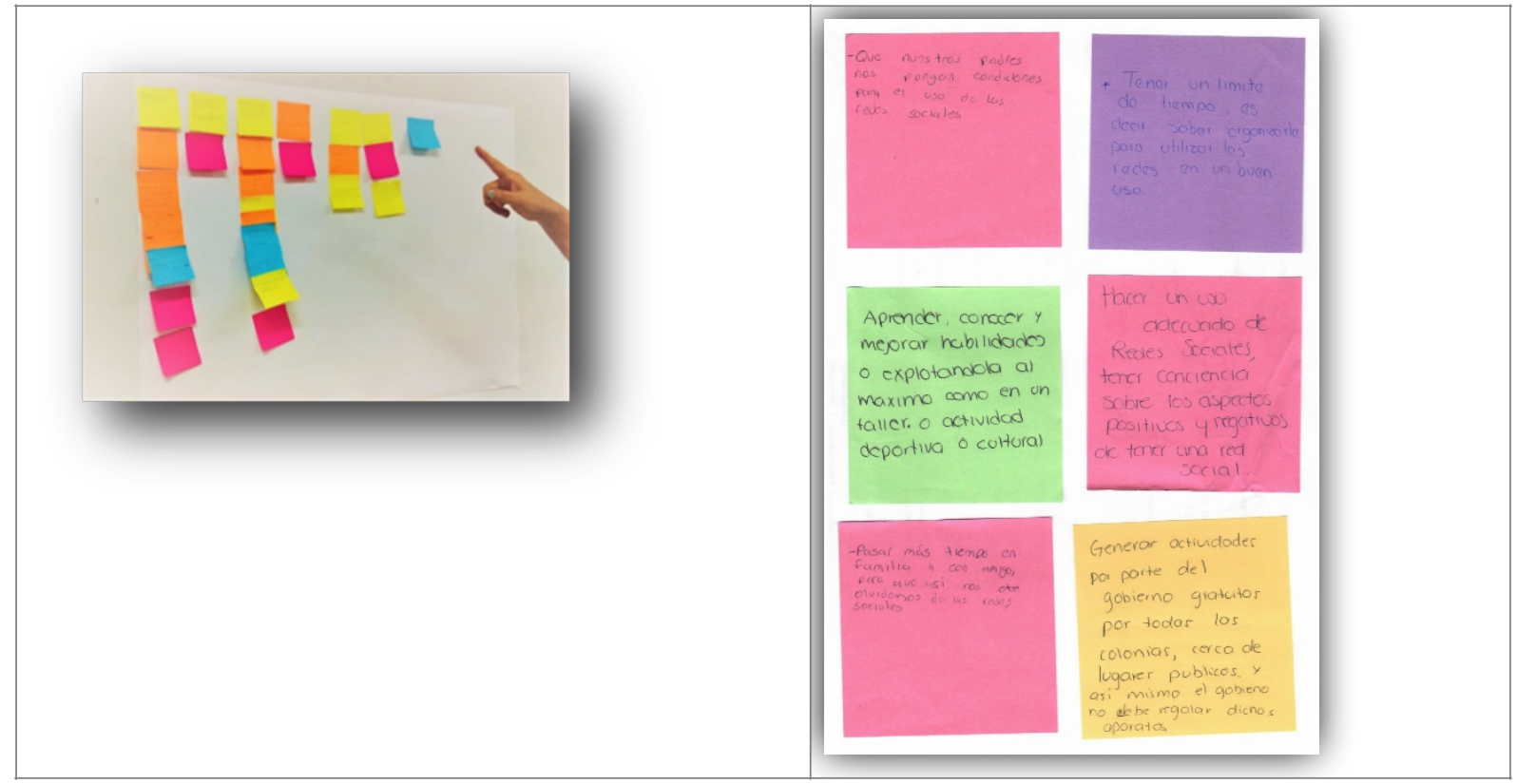

Figure 2. The proposed ideas are shared. / Source: Own elaboration

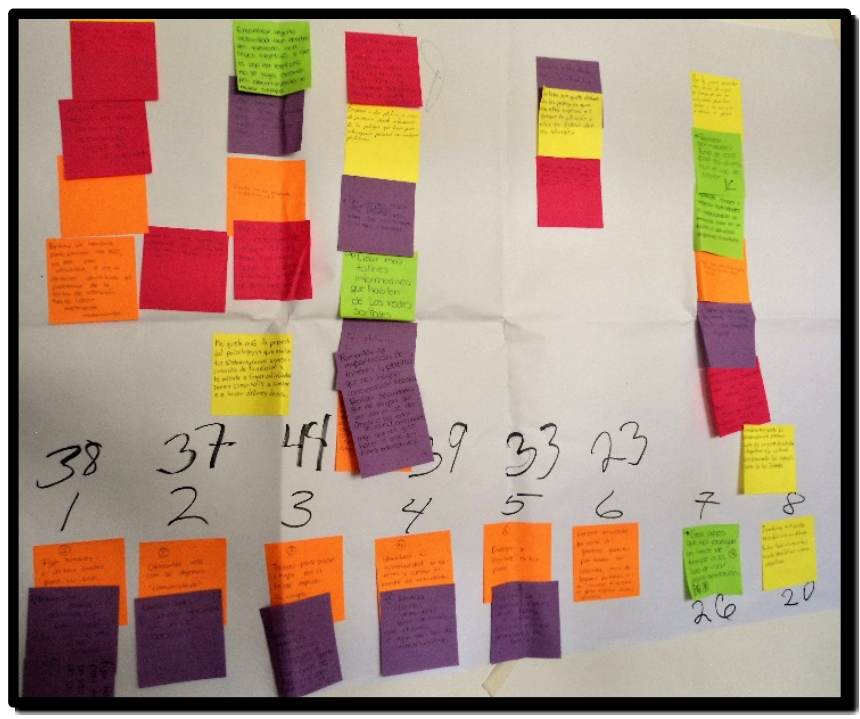

Figure 3. Speech, review and analysis of the team tasks./ Source: Own elaboration 


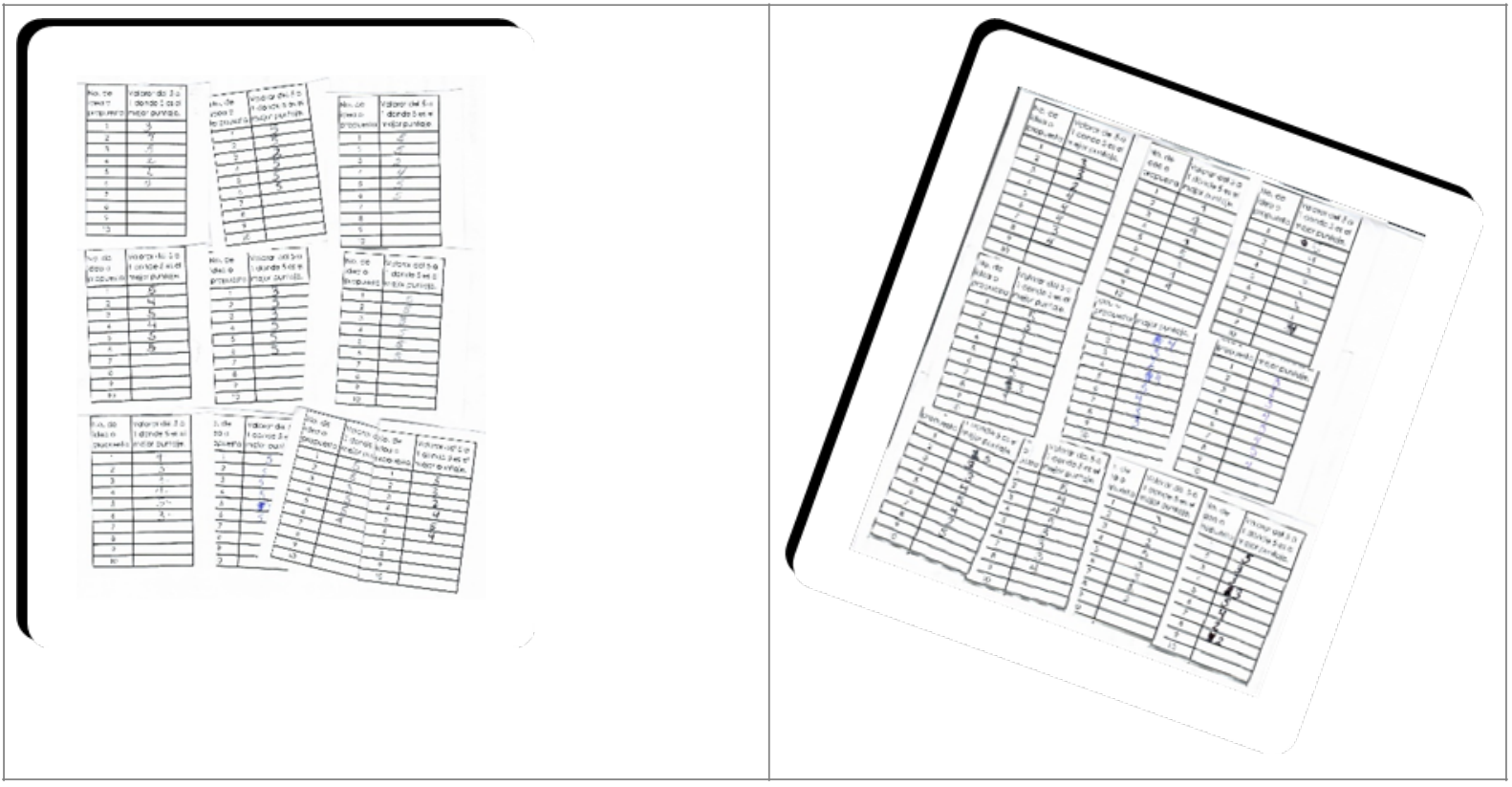

Figure 4. Questionnaires are voted and classified./ Source: Own elaboration

We initiate by presenting the results obtained with the students and later with the teachers-counselors-parents group. We will offer in the first place the results that each of the NG's performed, and then we synthesize both. There is, as a final part, a joint evaluation of the contributions in both groups.

When we start with the students from the first campus, we point out that the participants selected five measures:

1) Coexistence, appraisement, enjoyment and establishing relationships with people around us, relatives and Friends.

2) Searching and performing amusing activities like: Sports, learning new things, studying.

3) Participating in workshops to make handcrafts or amusing activities

4) The usage of social media and internet for academic purposes

5) The identification and differentiation of the types of content in social media and internet: junk or real information.

We present in chart 1 the different orders indicated by the 10 participants when they selected the items in de NG's. In order to obtain total scores, it must be said that the scale given was from 5 to the first choice, 4 to the second and so on.

\begin{tabular}{|l|l|l|l|l|l|}
\hline & Choice1 & Choice 2 & Choice 3 & Choice 4 & Choice 5 \\
\hline studnt.1 & 1 & 2 & 3 & 4 & 5 \\
\hline studnt.2 & 3 & 4 & 5 & 2 & 1 \\
\hline studnt.3 & 1 & 2 & 3 & 4 & 5 \\
\hline studnt.4 & 4 & 5 & 3 & 1 & 2 \\
\hline studnt.5 & 1 & 2 & 3 & 4 & 5 \\
\hline
\end{tabular}




\begin{tabular}{|l|l|l|l|l|l|}
\hline studnt.6 & 2 & 1 & 5 & 3 & 4 \\
\hline studnt.7 & 2 & 1 & 3 & 5 & 4 \\
\hline studnt.8 & 2 & 1 & 3 & 4 & 5 \\
\hline studnt.9 & 2 & 1 & 3 & 4 & 5 \\
\hline studnt.10 & 2 & 3 & 1 & 5 & 4 \\
\hline Total & 40 & 39 & 27 & 24 & 20 \\
\hline \% final score & 26.67 & 26 & 18 & 16 & 13.33 \\
\hline
\end{tabular}

Chart 1. Choices taken from the first proposal

Source: Own elaboration

As you can observe, the first choice obtained the higher score of cards with the second choice $(40 \%)$, the second choice with the first score with the first choice $(50 \%)$, the third option with the third selection $(60 \%)$, the option number 4 with the fourth choice $(40 \%)$ and the fifth one with the fifth choice $(50 \%)$.

In the chart No. 2, we present the final scores reached in the five selections.

\begin{tabular}{|l|l|}
\hline Options & Score \\
\hline $\begin{array}{l}\text { Coexistence, appraisement, enjoyment and establishing relationships } \\
\text { with people around us, relatives and Friends. }\end{array}$ & 40 \\
\hline $\begin{array}{l}\text { Searching and performing amusing activities like: Sports, learning new } \\
\text { things, studying. }\end{array}$ & 39 \\
\hline Participating in workshops to make handcrafts or amusing activities. & 27 \\
\hline The usage of social media and internet for academic purposes. & 24 \\
\hline $\begin{array}{l}\text { The identification and differentiation of the types of content in social } \\
\text { media and internet: junk or real information. }\end{array}$ & 20 \\
\hline
\end{tabular}

Chart 2: Final scores

Source: own elaboration

Besides these 5 selected options, we observed that there were other proposals in the NG's that were not considered in the end, and these are:

- Self-regulation: the organization, regulation and establishment of periods among 30 to 60 minutes to use mobile devices for social media, playing and using internet.

- To give the mobile device a correct worth: to communicate with it.

- The regulation from parents and counselors so they allow a reasonable time, with the only exception for school projects.

The proposals shown by the students from the fist campus to prevent the excessive use of OSN were in different directions, some were about rules to be observed by the person's principles (Coexistence, appraisement, enjoyment and establishing relationships with people around us, relatives and Friends), others are referred to shuttle different activities to use spare time (Searching and performing amusing activities like: Sports, learning new things, studying and Participating in workshops to make handcrafts or amusing activities), there were also some about the knowledge of positive use for Social media (The usage of social media and internet for academic purposes, the 
identification and differentiation of the types of content in social media and internet: junk or real information).

As far as it is concerned about campus No. 2, the five options to identify were:

1) Workshops for parents and children to explain the use of social media and internet and knowing the risks involved. Tot rain and transmit the information about these risks since Elementary school grade.

2) Identification of the individual level of vulnerability when using social media and performing activities such as sports.

3) Self-regulation: To set schedules, limits and rules to use social media and apps.

4) The use of mobile devices just to communicate and social media with specific purposes.

5) The search of dialogue and communication as well as having activities with the family.

Chart 3 presents different orders indicated by the 10 NG's participants.

\begin{tabular}{|c|c|c|c|c|c|}
\hline & Choice1 & Choice 2 & Choice 3 & Choice 4 & Choice 5 \\
\hline Studnt. 1 & 1 & 3 & 2 & 4 & 5 \\
\hline Studnt. 2 & 2 & 1 & 4 & 3 & 5 \\
\hline Studnt. 3 & 2 & 3 & 1 & 4 & 5 \\
\hline Studnt. 4 & 1 & 4 & 2 & 5 & 3 \\
\hline Studnt. 5 & 2 & 5 & 4 & 3 & 1 \\
\hline Studnt. 6 & 2 & 5 & 4 & 1 & 3 \\
\hline Studnt. 7 & 4 & 2 & 3 & 1 & 5 \\
\hline Studnt. 8 & 2 & 1 & 4 & 5 & 3 \\
\hline Studnt. 9 & 1 & 3 & 4 & 2 & 5 \\
\hline Studnt.10 & 4 & 2 & 3 & 5 & 1 \\
\hline Total & 39 & 31 & 29 & 27 & 24 \\
\hline$\%$ Final score & 26 & 20.67 & 19.33 & 18 & 16 \\
\hline
\end{tabular}

Chart 3. Choices taken from the first proposal.

Source: Own elaboration.

These final scores were obtained by the next evaluations offered in chart 6 , and they show that the first received the highest set of cards, validated with " 2 " $(50 \%)$ the second option with the third choice $(30 \%)$, the third option with the third choice $(50 \%)$ the option number four with the fifth choice $(30 \%)$ and the fifth option with fifth choice $(50 \%)$.

Besides these five options validated in the group, the students indicated three extra choices:

- The use of a diary to write the positive and negative experiences when surfing the internet and using Social media.

- The diversity of free activities provided by government so the youngsters could be in the neighborhood, public areas and electronic devices should not be provided. 
- There should be apps to set time limits in the use of other apps, or verifying if the already existing apps can do that.

In chart No. 4, we present the final scores reached by the different proposals.

\begin{tabular}{|l|c|}
\hline Elements & Score \\
\hline $\begin{array}{l}\text { Workshops for parents and children to explain the use of social media and inter- } \\
\text { net and knowing the risks involved. Tot rain and transmit the information about } \\
\text { these risks since Elementary school grade. Workshops to inform and prepare } \\
\text { Young people about Social Media usage. }\end{array}$ & 39 \\
\hline $\begin{array}{l}\text { Identification of the individual level of vulnerability when using social media and } \\
\text { performing activities such as sports or having cultural events to develop the } \\
\text { youngster's abilities. }\end{array}$ & 31 \\
\hline $\begin{array}{l}\text { Self-regulation: To set schedules, limits and rules to use social media and apps. } \\
\text { If addiction is presented, search for professional psychological advice. }\end{array}$ & 29 \\
\hline $\begin{array}{l}\text { The use of mobile devices just to communicate and social media with specific } \\
\text { purposes. }\end{array}$ & 27 \\
\hline $\begin{array}{l}\text { The search of dialogue and communication as well as having activities with the } \\
\text { family }\end{array}$ & 20 \\
\hline
\end{tabular}

Chart 4. Final scores obtained by the 5 choices the students from the second campus performed.

Source: Own elaboration.

In this case, the option selected by the students to prevent the abuse of surfing on the internet were in different leads, some would establish the options of the students in the campus: to enhance several activities to spend time ("Identification of the individual level of vulnerability when using social media and performing activities such as sports or having cultural events to develop the youngster's abilities), to set measures of personal principles ("The search of dialogue and communication as well as having activities with the family"), to educate them in self-control when surfing the internet ("Self-regulation: To set schedules, limits and rules to use social media and apps. If addiction is presented, search for professional psychological advice" and "Workshops for parents and children to explain the use of social media and internet and knowing the risks involved. Training and transmit the information about these risks since Elementary school grade. Workshops to inform and prepare Young people about Social Media usage".

The summary of the proposals generated by both NG's students were:

- Workshops for parents and children to explain the use of social media and internet and knowing the risks involved. Tot rain and transmit the information about these risks since Elementary school grade. Workshops to inform and prepare Young people about Social Media usage. (choice 1 , campus 1 ).

- Searching and performing amusing activities like: Sports, learning new things, studying or having cultural events to develop the youngster's abilities. Participating in workshops to make handcrafts or amusing activities (choice 2, campus 1 and 2)

- Coexistence, appraisement, enjoyment and establishing relationships with people around us, relatives and Friends. The search of dialogue and communication as well as having activities with the family (choice 1 campus 1 and choice 5 campus 2)

- The usage of social media and internet for academic purposes (choice 4 campus 1 )

- Self-regulation: To set schedules, limits and rules to use social media and apps. If addiction is presented, search for professional psychological advice (choice 3, campus 2) 
- The identification and differentiation of the types of content in social media and internet: junk or real information. (choice 5 , campus 1 )

Once the results obtain have been presented, it is now the time to continue with the ones obtained from de teachers-counselors-parents NG's. We start with the results from teachers in campus 1. The first thing to mark is that the choices we obtained from NG were:

1. The awareness of risks is necessary in youngsters about what they post in the internet because of the vulnerability to be exhorted, kidnapped or banned; they also must know about social impact that abuse of social media have in their personal future life. They suggested to enhance campaigns to make this awareness present in youth about the use of OSN and the internet.

2. The time setting for social media use, so they have the technology with a purpose. The control should be at home with specific Schedule. Also, at home the rules and areas should be provided as well as time of use.

3. To instruct and raise awareness about the Social media use with school purposes.

4. Campaigns and chats with parents "to educate everyone" about social media and the internet.

5. The promotion of healthy relationships in everyday life and through the internet.

Chart number 5 presents the score given by the participants.

\begin{tabular}{|l|l|l|l|l|l|}
\hline & Choice 1 & Choice 2 & Choice 3 & Choice 4 & Choice 5 \\
\hline Part.1 & 1 & 2 & 3 & 4 & 5 \\
\hline Part.2 & 1 & 2 & 4 & 5 & 3 \\
\hline Part.3 & 4 & 5 & 3 & 1 & 2 \\
\hline Part.4 & 1 & 3 & 2 & 4 & 5 \\
\hline Part.5 & 3 & 2 & 1 & 5 & 4 \\
\hline Part.6 & 2 & 1 & 3 & 4 & 5 \\
\hline Part.7 & 3 & 4 & 5 & 1 & 2 \\
\hline Part.8 & 1 & 2 & 5 & 3 & 4 \\
\hline Part.9 & 3 & 2 & 1 & 5 & 4 \\
\hline Part.10 & 5 & 4 & 2 & 3 & 1 \\
\hline Total & 35 & 33 & 31 & 26 & 25 \\
\hline \% Score & 23.33 & 22 & 20.67 & 17.33 & 16.67 \\
\hline
\end{tabular}

Chart 5. Choices about the first proposal.

Source: Own elaboration

The choice 1 obtained the major percentage of valuated cards with a score of "1" $(40 \%)$ : choice with the value "2" $(50 \%)$, the score " 3 " with value $3(30 \%)$, choice 4 with value of $3(30 \%)$ and choice 5 with $4(30 \%)$ and $5(30 \%)$ points.

Besides these five final options, the teachers-counselors-parents from the first campus, indicated other two choices: 
- To include Social Media in academic activities. It is suggested the use of suitable educational platforms for students

- $\quad$ Sport activities should be promoted

We now present the weighted score from the percentages given by teachers from campus 1 (chart $6)$.

\begin{tabular}{|l|c|}
\hline Elements & Score \\
\hline $\begin{array}{l}\text { The awareness of risks is necessary in youngsters about what they post in the } \\
\text { internet because of the vulnerability to be exhorted, kidnapped or banned; they } \\
\text { also must know about social impact that abuse of social media have in their } \\
\text { personal future life. They suggested to enhance campaigns to make this aware- } \\
\text { ness present in youth about the use of OSN and the internet. }\end{array}$ & 35 \\
\hline $\begin{array}{l}\text { The time setting for social media use, so they have the technology with a pur- } \\
\text { pose. The control should be at home with specific schedule. Also, at home the } \\
\text { rules and areas should be provided as well as time of use. }\end{array}$ & 33 \\
\hline $\begin{array}{l}\text { To instruct and raise awareness about the Social media use with school purpo- } \\
\text { ses }\end{array}$ & 31 \\
\hline $\begin{array}{l}\text { Campaigns and chats with parents "to educate everyone" about social media } \\
\text { and the internet. }\end{array}$ & 26 \\
\hline The promotion of healthy relationships in everyday life and through the internet. & 25 \\
\hline
\end{tabular}

Chart 6. Weighted scores from the scales obtained from teachers in campus 1.

Source: Own elaboration

Then, we present the resultant scores from parents in campus 2, with five options framed as follows:

1) To rise student's awareness about OSM and Internet use through close talks, researches, among others. Dialogue should be enhanced to talk about Social Media.

2) The development of pedagogical strategies to encourage learning in school areas so the students don 't divert to the mobile devices.

3) Parents must be aware of what Social Media is, the use and abuse through close talks and meetings.

4) Students must establish agreements for mobile, internet and social media use, as well as the consequences if the rules are not fulfilled.

5) Skills for "face to face" abilities should be developed. Leisure activities should be proposed to coexist in classrooms.

Chart number 7 presents the score from the ten participants in campus 5 


\begin{tabular}{|l|l|l|l|l|l|}
\hline & Choice 1 & Choice 2 & Choice 3 & Choice 4 & Choice 5 \\
\hline Part.1 & 1 & 2 & 3 & 5 & 3 \\
\hline Part.2 & 2 & 5 & 4 & 1 & 3 \\
\hline Part.3 & 3 & 1 & 4 & 5 & 2 \\
\hline Part.4 & 1 & 3 & 4 & 2 & 5 \\
\hline Part.5 & 2 & 1 & 3 & 4 & 5 \\
\hline Part.6 & 1 & 4 & 5 & 2 & 3 \\
\hline Part.7 & 2 & 3 & 1 & 4 & 5 \\
\hline Part.8 & 5 & 4 & 1 & 2 & 4 \\
\hline Part.9 & 1 & 2 & 3 & 5 & 4 \\
\hline Part.10 & 1 & 2 & 3 & 4 & 5 \\
\hline Total results & 41 & 33 & 30 & 26 & 20 \\
\hline \% Score & 27.33 & 22 & 20 & 17.33 & 13.33 \\
\hline
\end{tabular}

Chart 7. Choices obtained from first proposal.

Source: Own elaboration.

In the case of option 1 , it obtained the highest percentage of punctuated cards with a score of 1 $(50 \%)$; for choice " 2 " with 2 points $(30 \%)$, the number " 3 " with 3 points $(40 \%)$, and choice 4 with 3 points (30\%), $4(30 \%)$ and 5 (30\%); finally, choice number 5 with 5 points (40\%).

Chart 8 presents the final score obtained in the five selected choices.

\begin{tabular}{|l|c|}
\hline Elements & Score \\
\hline $\begin{array}{l}\text { To rise student's awareness about OSM and Internet use through close talks, re- } \\
\text { searches, among others. Dialogue should be enhanced to talk about Social Media }\end{array}$ & 41 \\
\hline $\begin{array}{l}\text { The development of pedagogical strategies to encourage learning in school areas } \\
\text { so the students don 't divert to the mobile devices. }\end{array}$ & 33 \\
\hline $\begin{array}{l}\text { Parents must be aware of what Social Media is, the use and abuse through close } \\
\text { talks and meetings. }\end{array}$ & 30 \\
\hline $\begin{array}{l}\text { Students must establish agreements for mobile, internet and social media use, as } \\
\text { well as the consequences if the rules are not fulfilled. }\end{array}$ & 26 \\
\hline $\begin{array}{l}\text { Skills for "face to face" abilities should be developed. Leisure activities should be } \\
\text { proposed to coexist in classrooms. }\end{array}$ & 20 \\
\hline
\end{tabular}

Chart 8. Final scores.

Source: Own elaboration.

In addition to these options, participants offered the next one:

- The inclusion of mobiles during classroom activities with educative purposes.

Once the proposals from teachers-counselors-parents in two campus have been unified, the definite final choices were: 
- The awareness of risks is necessary in youngsters about what they post in the internet because of the vulnerability to be exhorted, kidnapped or banned; they also must know about social impact that abuse of social media have in their personal future life. They suggested to enhance campaigns to make this awareness present in youth about the use of OSN and the internet. (choice 1 campus 1 and 2)

- The development of pedagogical strategies to encourage learning in school areas so the students don 't divert to the mobile devices (choice 2 campus 2 )

- Students must establish agreements for mobile, internet and social media use, as well as the consequences if the rules are not fulfilled. To educate and rise awareness about the use of OSN in school areas. Schedule and use time limitation. (choice 2 campus 1, choice 4 campus 2)

- Campaigns and chats with parents "to educate everyone" about social media and the internet. Parents must be aware of what Social Media is, the use and abuse through close talks and meetings ( choice 4 campus 1 , choice 3 campus 2 )

- The time setting for social media use, so they have the technology with a purpose. The control should be at home with specific schedule. Also, at home the rules and areas should be provided as well as time of use (choice 2 campus 1 ).

- The promotion of healthy relationships in everyday life and through the internet and the development of Skills for "face to face" abilities. Leisure activities should be proposed to coexist in classrooms as well as sport activities. (choice campus 1 and 2)

- To include Social Media in academic activities. It is suggested the use of suitable educational platforms for students. Activities with mobiles during classroom with educative purposes should be contemplated too. (choice 5, campus 1)

As the analysis of the proposals from parents-counselors-parents and students is done, now we present those proposals which both NG agree and those which each group convey.

Chart 9 has the agreements in both groups.

Coincidence between teachers-counselors-parents and students.

Guided actions for parents about use and abuse of SM and the Internet.

Guided actions for students to explain the use of Social Media and the internet. Enhance the knowledge about the impact in their future professional and personal lives if posting in social media.

The promotion of "face to face" relationships with families and friends.

Searching and performing amusing activities like: Sports, learning new things, studying or having cultural events to develop the youngster's abilities. Participating in leisure activities: cultural and sport dues. .

Time Schedule to regulate use of mobile phones, the internet and social media.

Using social media for academic purposes.

Chart 9. Agreements among groups.

Source: Own elaboration

On the other hand, students contributed with two actions independently:

- Student's Self-regulation 
- The identification and differentiation of the contents through internet and social media: junk and real information.

As far as the teacher-counselors-parent's groups, the individual choices their offered these:

- To include mobile phones as a pedagogical tool.

- The control should be at home with specific schedule. Also, at home the rules and areas should be provided as well as time of use

- The development of pedagogical strategies to encourage learning in school areas so the students don 't divert to the mobile devices

\section{Discussion and conclusion}

The first thing to point out is that we found a high level of agreement in the measures both students and teachers-counselors-parents propose to treat the addiction problem to ONS. Thus, these proposals are valid to both groups and can be usefully implemented. Beside this, one of the meaningful circumstances is that both collectives participating in the study agree on the need to adopt measures in order to regulate time of use. Even students mentioned self-regulation. This element is considered one of the cognitive skills students should have to develop efficiently in the IT's use (Cabero, 2013).

One of the discoveries we detected is that in both groups the participants don't consider the addiction to social media as something isolated, but they connect it as the consequence of addiction to mobile phones and to the internet. To some extent, this is supported by different authors that believe there is a symbiosis between these technologies so we can consider as a certain type of internet addiction (Osorio, Molero, Pérez and Mercader, 2014; Jasso, López and Díaz, 2017; Arnavut, Nuri and Direktör, 2018; Sahin, 2018; Delgado, 2019). Peñalva and Napal $(2019,60)$ recently exposed: "Student bodies who have a mobile phone at their fingertips are increasing in younger ages. It gets as $70 \%$ during 5 th grade and $85 \%$ by 6 th grade". These authors also say that "The use of Internet can not be unattached to mobile phones and their presence is increasing meaningfully as the courses continue". (Peñalva and Napal, 2019, 61). This suggest that measures or plans must be established to solve addiction problems by using wide perspectives than just the simple social media ones.

On the other hand, this problem should not be "attacked" from an only frontal view, but educative institutions, as well as teachers, students and parents, have to adopt measures to address the situation. In the case of the parents situation, it is necessary that they know the possible problems and consequences that the abuse of social media and other type of technologies could bring to their children. Martínez-Piñeiro, Vila and Gewerc (2018) have expressed that families represent a significant role in the digital competence construction in youngsters and teenagers, and their social status determines different behaviors towards the permissiveness in technological use given to the kids from parents.

About this, teachers claim that there should be a restricted time Schedule and places for using social media, as well as the consensus of the regulations for teenagers. Moreover, García-Ramos, Lacalle, Valbuena and Polaino-Lorente (2019) obtained in their research that the time parents spend with their kids has a direct influence in children's self-esteem and it improves their ability to establish social relationships, and also has an improvement in pro-social attitudes and other aspects.

Among other conclusions this work suggest that adopted measures should not be only educative in the matter of use of technologies, but it is also about the individuals themselves. It's prior to insist on building a new type of personality of students so they can boost the development of activities not related to technology and this would empower "face to face" communicative role models. This 
situation occurs, in our point of view, if educative institutions work to empower not only the general knowledge acquisition for students, but also the "emotional intelligence" and the "soft skills" such as leadership, optimism, empathy, common sense, humor sense, interpersonal relationships or the ability to collaborate and negotiate.

Another measure appearing is the lead to incorporate these technologies, social media and mobile phones in educative tasks designed by the teachers so the students can see other ways to use both technologies and this would help them avoid or simply perform negative or pernicious uses with these technologies. But this circumstance enhances another debate referred to the capacity of teachers to do that.

It is highly interesting that teachers themselves claim the need to develop pedagogical innovative strategies that motivate students, so they lead them to forget about mobiles diversion. This fact would ease the inclusion of new technologies in educative practices, as UNESCO (2016) published: "The evidence of PISA tells us that those teachers who are willing and well prepared to create learning practices for guiding students, can include the use of technologies in their lessons. Some examples of these learning practices are: Group activities, individual learning and Project learning" (UNESCO, 2016: 20).

Our study requires to be replicated in other contexts so this could become a future line of research. At the same time and because of the appearance of the need to educate parents, students and teachers about this matter, we believe these results can come useful to elaborate audiovisual materials in different format (video, multimedia, websites...) so they can be used to capacitate and evaluate them with the aid of parents, teachers and students.

We finally point out that it could have a significant meaning to consider other options that were not chosen within the five positions of the NGT, but they can provide important elements to avoid the abuse and addiction to OSM: to establish actions plans in the government as well as the development of apps to regulate the time of use of these elements. 


\section{References}

Banyai, F., Zsila, A., Király, O., Maraz, A., Elekes, Z., Griffiths, M.D., Andreassen, C. \& Demetrovics, D. (2017). Problematic social media use: results from a large-scale nationally representative adolescent sample. PLOS ONE, 12(1), 1-13.

Basteiro, J., Robles, A., Juarros, J. \& Pedrosa, I. (2013). Adicción a las redes sociales: creación y validación de un instrumento de medida. Revista de Investigación y Divulgación en Psicología y Logopedia, 3(1), 2-8.

Cabero, J. (2013). El aprendizaje autorregulado como marco teórico para la aplicación educativa de las comunidades virtuales y los entornos personales de aprendizaje. Revista Electrónica Teoría de la Educación: Educación y Cultura en la Sociedad de la Información, 14(2), 133-156

Cañón, S.C., Castaño, J.J., Hoyos, D.C., Jaramillo, J.C., Leal, D.R., Rincón, R., Sánchez, E.A. y Ureña, L.E. (2016). Uso de internet y su relación con la salud en estudiantes universitarios de la ciudad de Manizales (Caldas-Colombia), 2015-2016. Archivos de Medicina, 16(2), 312-325.

Chóliz, M. \& Marco, C. (2012). Adicción a Internet y redes sociales. Tratamiento psicológico. Madrid: Alianza.

Delbecq, A. \& Andrew, V.A. (1971). Group Process Model For Problem Identification and Program Planning. Journal of Applied Behavioral Science, 7, 466-492.

Dong, G., Lin, X., Zhou, H. \& Lu, Q. (2014). Cognitive flexibility in internet addicts: fMRI evidence from difficultto-easy and easy-to-difficult switching situations. Addictive Behaviors, 39, 677-683. doi:10.1016/ j.addbeh.2013.11.028.

Escurra, M. \& Salas, E. (2014). Construcción y validación del cuestionario de adicción a redes sociales (ARS). LIBERABIT, 20(1), 73-91.

Yu. S., Wu. A., \& Pesigan. I. (2016). Cognitive and psychosocial health risk factors of social networking addiction. International Journal of Mental Health and Addiction, 14(4), 550-564. doi: 10.1007/s11469-0159612-8.

Xanidis, N., \& Brignell. C. (2018). The association between the use of social network sites. sleep quality and cognitive function during the day. Computers in Human Behavior, 55, 121-126. doi: http://dx.doi.org/ 10.1016/j.chb.2015.09.0040747-5632/.

Gordo. A., García. A., De Rivera. J., \& Díaz-Catalán, C. (2018). Jóvenes en la encrucijada digital. Itinerarios de socialización y desigualdades en los entornos digitales. Madrid: Morata.

Malo. S., Martín. M., \& Viñas. F. (2018). Uso excesivo de redes sociales: Perfil psicosocial de adolescentes españoles. Comunicar, 56, 101-110. doi: https://doi.org/10.3916/C56-2018-10.

Martín, A., Pazos. M., Montilla, M., \& Romero, C. (2016). Una modalidad actual de violencia de género en parejas de jóvenes: las redes sociales. Educación XXI, 19(2), 405-429. doi: http://dx.doi.org/10.5944/ educxx1.16473.

Martínez-Ferrer, B., \& Moreno, D. (2017). Dependencia de las redes sociales virtuales y violencia escolar en adolescentes. International Journal of Developmental and Educational Psychology. INFAD Revista de Psicología, 1(1), 105-114. doi: https://doi.org/10.17060/ijodaep.2017.n1.v2.923.

Lee, Z., \& Cheung, C. (2014). Problematic use of social networking sites: The role of self-esteem. International Journal of Business and Information, 9(2). 143-159.

Ganesh, A., Pragyakumari, D., Ramsudarsan, N, Rajkumar, M., Shyam, S. \& Balaji, S. K. (2017). Self-reported behaviour about internet addiction among medical and paramedical students. Journal of Clinical \& Diagnostic Research, 11(10), 10-13. doi:10.7860/JCDR/2017/26278.10775

García-Ramos, J. M., Lacalle, M., Valbuena, C. \& Polaino-Lorente, A. (2019). Relaciones familiares y tiempo compartido y su efecto en el bienestar de los adolescentes. Revista Complutense de Educación, 30 (3), 895-915.

Harvey, N. \& Holmes, C.A. (2012). Nominal group technique: an effective method for obtaining group consensus. International Journal of Nursing Practice, 18, 188-194. doi: https://doi.org/10.1111/ ijn.2012.18.issue-2. 
Hugé, J. \& Mukherjee, N. (2018). The nominal group technique in ecology \& conservation: Application and challenges. Methods in Ecology and Evaluation, 9, 33-41. doi: 10.1111/2041-210X.12831.

Lacka, E., Wong, T.C., Mohamed, W. \& Haddoud, M.Y. (2021). Can digital technologies improve students efficiency? Exploring the role of Virtual Learning Environment and Social Media use in Higher Education. Compurters \& Education, 163, 6-11. doi: https://doi.org/10.1016/j.compedu.2020.104099

Lennon, R., Glasper, A. \& Carpenter, D. (2012). Nominal Group Technique: its utilisation to explore the rewards and challenges of becoming a mental health nurse, prior to the introduction of the all graduate nursing curriculum in England. Working Papers in Health Sciences, 1(2), 1-5.

Liu, Ch. y Mab, J. (2018). Development and validation of the Chinese social media addiction scale. Personality and Individual Differences, 134, 55-59. doi: https://doi.org/10.1016/j.paid.2018.05.046.

Manera, K., Hanson, C., Gutman, T. \& Tong, A. (2018). Consensus Methods: Nominal Group Technique. En P. Liamputtong (ed.), Handbook of Research Methods in Health Social Sciences, 1-12. doi: https:// doi.org/10.1007/978-981-10-2779-6_100-1.

Martínez-Piñeiro, E., Vila, E. \& Gewerc, A. (2018). El papel de la familia en la construcción de la competencia digital. Revista Ibérica de Sistemas e Tecnologias de Informação, 28, 1-13. doi: 10.17013/risti.28.113.

McMillan, S. S., Kelly, F., Sav, A., Kendall, E., King, M.A., Whitty, J.A. \& Wheller, A.J. (2017). Using the nominal group technique: How to analyse across multiple groups. Health Services Outcomes Research Methods, 14, 92-108. doi: https://doi.org/10.1007/s10742-014-0121-1.

Meena, K., Navpreet, K., Kavnet, C., Navreet, K., Parminder, K. \& Parwinder, K. (2015). Descriptive study to assess the prevalence and effects of internet addiction among undergraduates. Baba Farid University Nursing Journal, 8(1), 58-62.

Olaz, A. (2012). La técnica de Grupo Nominal como herramienta de investigación cualitativa. Madrid: Bohodón Ediciones.

Orosz, G., Tóth-Király, Y. \& Bőthe, B. (2016). Four facets of Facebook intensity - The development of the Multidimensional Facebook Intensity Scale. Personality and Individual Differences, 100, 95-104. doi: http://dx.doi.org/10.1016/j.paid.2015.11.038.

Peñalva, A. \& Napal, M. (2019). Hábitos de uso de Internet en niños y niñas de 8 a 12 años: un estudio descriptivo. Hamut'ay, 6(2), 55-68. doi: http://dx.doi.org/10.21503/hamu.v6i2.1775.

Peña, A., Estrada, C., Debbie, R., Taylor, B. \& Burton, M. (2012). Nominal group technique: A brainstorming tool for identifying areas to improve pain management in hospitalized patients. Journal of Hospital Medicine, 77(5), 416-410.

Rice, D.B., Cañeda-Ayala, M., Turner, K.A., Gumuchian, S.T., Malcarne, V.L., Hagedoom, M. \& Thombs, B.D. (2018). Use of the nominal group technique to identify stakeholder priorities and inform survey development: an example with informal caregivers of people with scleroderma. BMJ Open. doi:10.1136/ bmjopen-2017-019726.

Rodríguez-Gallego, M. R. (2014). Análisis de los factores del rendimiento académico de los estudiantes de Pedagogía desde la técnica de grupo nominal y método Delphi. Educatio Siglo XXI, 32 (2), 245-266.doi: https://doi.org/10.6018/j/202241

Rücker, J., Akre, Ch., Berchtold, A. \& Suris, J.C. (2015). Problematic Internet use is associated with substance use in young adolescents. Acta Paediatrica, 104, 504-507. doi:10.1111/apa.1297.

Sigerson, L. \& Cheng, C. (2018). Scales for measuring user engagement with social network sites: A systematic review of psychometric properties. Computers in Human Behavior, 83, 87-105. doi: https://doi.org/ 10.1016/j.chb.2018.01.023.

Sahin, C. (2018). Social Media Addiction Scale - Student Form: The Reliability and Validity Study. TOJET: The Turkish Online Journal of Educational Technology, 17(1), 168-182.

Salcines-Talledo, I., González-Fernández, N.\& Briones, E. (2020). The Smartphone as a Pedagogic Tool. Studen Profiles as related to its Use and Knolwledge. Journal of New Aprroaches in Educational Research, 9(1), 91-109. 
Simó, C., Martínez, A., Ballester, M.L. \& Domínguez, A. (2017). Instrumentos de evaluación del uso problemático del teléfono móvil/smartphone. Salud y drogas, 17(1), 5-14.

Tutgun-Ünal, A. \& Deniz, L. (2015). Development of the Social Media Addiction Scale. AJIT-e: Online Academic Journal of Information Technology, 6(2)1, 51-70. doi: 10.5824/1309-1581.2015.4.004.x.

Ávila. D., Pardo. E., \& Muñoz. M. (2018). Escala de Adicción al Internet de Lima (EAIL): Análisis psicométrico. Revista Iberoamericana de Psicología, 11(3). 100-107. doi: https://doi.org/ 10.33881/2027-1786.rip.11309

Unesco (2016). Tecnologías digitales al servicio de la calidad educativa. Unesco: Santiago de Chile. doi: http:// dx.doi.org/10.12795/pixelbit.2018.i53.11

Valencia, R. \& Castaño, C. (2019). Use and abuse of social media by adolescents: a study in Mexico. Pixel-Bit. Revista de Medios y Educación, 54, 7-28. doi: https://doi.org/10.12795/pixelbit.2019.i54.01.

Vander, F. (2015). Not just another focus group: making the case for the nominal group technique in criminology. Crime Science, 4(5), 1-12. doi: 10.1186/s40163-014-0016-z.

Varga-Atkins, T., (coord.) (2011). The Nominal Group Technique: a practical guide for facilitators. ELESIG Small Grants Scheme. Liverpool: University of Liverpool.

Wegmann, E., Stodt, B. \& Brand, M. (2015). Addictive use of social networking sites can be explained by the interaction of Internet use expectancies, Internet literacy, and psychopathological symptoms. Journal of Behavioral Addictions, 4(3), 155-162. 